\title{
MRR
}

\section{Genetic analysis of oocyte and embryo production traits in Guzerá breed donors and their associations with age at first calving}

\author{
B.C. Perez ${ }^{1}$, M.G.C.D. Peixoto ${ }^{2}$, F.T. Bruneli ${ }^{2}$, P.V.B. Ramos ${ }^{3}$ and J.C.C. Balieiro ${ }^{4}$ \\ 1Programa de Pós-Graduação, Qualidade e Produtividade Animal, \\ Faculdade de Zootecnia e Engenharia de Alimentos, \\ Universidade de São Paulo, Pirassununga, SP, Brasil \\ ${ }^{2}$ Embrapa Gado de Leite, CNPGL, Juiz de Fora, MG, Brasil \\ ${ }^{3}$ Faculdade de Veterinária, Universidade Federal Fluminense, Niterói, RJ, Brasil \\ ${ }^{4}$ Departamento de Nutrição e Produção Animal, \\ Faculdade de Medicina Veterinária e Zootecnia, \\ Universidade de São Paulo, Pirassununga, SP, Brasil \\ Corresponding author: B.C. Perez \\ E-mail: brunocpvet@gmail.com \\ Genet. Mol. Res. 15 (2): gmr.15027583 \\ Received August 8, 2015 \\ Accepted November 26, 2015 \\ Published April 25, 2016 \\ DOI http://dx.doi.org/10.4238/gmr.15027583
}

ABSTRACT. The objective of this study was to estimate variance components for oocyte and embryo production traits in Guzerá breed female donors, and investigate their associations with age at first calving $\left(\mathrm{A}_{\mathrm{FC}}\right)$. The traits analyzed were the number of viable oocytes $\left(\mathrm{N}_{\mathrm{ov}}\right)$, the number of grade I oocytes $\left(\mathrm{N}_{\mathrm{GI}}\right)$, the number of cleaved embryos $\left(\mathrm{N}_{\mathrm{CLV}}\right)$, and viable embryos produced $\left(\mathrm{N}_{\mathrm{EMB}}\right)$, and the percentages of viable oocytes $\left(\mathrm{P}_{\mathrm{OV}}\right)$, grade I oocytes $\left(P_{G I}\right)$, cleaved embryos $\left(P_{C L V}\right)$, and viable embryos $\left(P_{E M B}\right)$. Data were obtained from 5173 ovary puncture and in vitro fertilization (IVF) sessions using 1080 Guzerá female donors of different ages, occurred from March 2005 to July 2013. Variables were log-transformed $\left(\log _{\mathrm{e}} \mathrm{X}+1\right)$ prior to analysis. (Co)variance components were estimated by restricted maximum likelihood (REML), using one- and two-trait animal models. 
Permanent environment and IVF sire (father of the embryos) random effects were included. Estimated heritabilities for $\mathrm{N}_{\mathrm{OV}}, \mathrm{N}_{\mathrm{Gl}}, \mathrm{N}_{\mathrm{CLV}}, \mathrm{N}_{\mathrm{EMB}}, \mathrm{P}_{\mathrm{OV}}$, $P_{G I}, P_{C L V}$, and $P_{E M B}$ were 0.19, 0.08, 0.16, 0.14, 0.04, 0.03, 0.01, and 0.07, respectively. Repeatabilities for count traits $\left(\mathrm{N}_{\mathrm{OV}}, \mathrm{N}_{\mathrm{Gl}}, \mathrm{N}_{\mathrm{CLV}}\right.$, and $\left.\mathrm{N}_{\mathrm{EMB}}\right)$ varied from 0.14 and 0.32 , higher than estimated for percentage traits $\left(P_{\text {oV }}, P_{G l}\right.$, $P_{C L V}$, and $P_{E M B}$ ), which varied from 0.01 to 0.08 . Selection for $N_{O V}$ may be more appropriate in breeding programs than selection for $\mathrm{N}_{\mathrm{EMB}}$, because of its strong genetic correlation (0.68) with $\mathrm{N}_{\mathrm{EMB}}$ and its greater time- and costeffectiveness. $A_{F C}$ was only weakly associated with the oocyte and embryo production traits, which indicates that there would be no effect on $A_{F C}$ when selecting for these traits.

Key words: Bivariate analysis; Genetic parameter; In vitro fertilization; Ovum pick-up; Permanent environment; Zebu cattle

\section{INTRODUCTION}

Animal reproductive technologies have been successfully used worldwide, increase the importance of female bovines in breeding programs (Guerreiro et al., 2014), and play an important role in improving the accuracy and intensity of selection for quantitative traits in both beef and dairy cattle. Approximately 1,275,874 embryos were produced globally in $2013,546,628$ of which were derived from in vitro technologies (IETS, 2014). In Brazil, which was responsible for $70.8 \%$ of the total in vitro embryos produced in the world in 2013 (IETS, 2014), ovary puncture (OPU) followed by in vitro embryo production (IVP) biotechnology is the main procedure for increasing the number of individuals of interest in Zebu cattle.

For the Brazilian Guzerá herd in particular, reproductive biotechnologies have played an important role since 1994, when a selection nucleus based on an embryo transfer program [multiple ovulation followed by embryo transfer (MOET) nucleus; Nicholas and Smith, 1983] was implemented (Penna et al., 2002). MOET, and more recently OPU, followed by IVP technologies, were used inside the nucleus, in order to accelerate the identification of genetically superior individuals.

In tropical pasture-based systems, in which Bos indicus x Bos taurus crosses are the predominant genetic group, and the maintenance of heterosis has always been an obstacle, IVP offers new possibilities in terms of improving production in commercial bovine herds. The process of transferring F1 crossbred embryos (produced in vitro) into F1 females in order to implement the continuous replacement of $\mathrm{F} 1$ animals and preserve maximum heterosis in commercial herds may be economically viable (Rutledge, 2004; Madalena, 2012), and increases beef and milk production in the tropics.

Reproductive traits are complex, as are reproductive biotechnology-related traits, because both must share a similar biological background. Previous studies have investigated nutrition (Ponter et al., 2012; Sales et al., 2015), heat stress (de Torres-Júnior et al., 2008; Baruselli et al., 2012), oocyte quality (Merton et al., 2009), in vitro fertilization (IVF) (Simões et al., 2013), intervals between sessions, and aspiration (Merton et al., 2003) as some of the significant effects that affect the results of IVP. Genetic components have shown to influence the outcome of both MOET (Tonhati et al., 1999; Peixoto et al., 2004; König et al., 2007) and OPU/IVP (Machado et 
al., 2006; Merton et al., 2009) techniques. However, most studies have investigated physiological, environmental, or technological factors that affect bovine embryo production. In the only study that accounted for additive genetic variation in OPU/IVP-related traits, Merton et al. (2009) reported heritabilities of 0.07 to 0.25 in Holstein cattle using a sire model. The authors emphasized the importance of embryo production in genomics (Merton et al., 2009). Considering that in the future genomic selection could be conducted at the embryo stages, a higher number of produced embryos per donor would result in greater selection pressure (Kadarmideen et al., 2015).

Little attention has been given to the genetic components involved in oocyte and embryo production in Zebu female donors subjected to OPU and IVF. Studies that have accounted for the genetic association between natural and artificial reproductive traits are few in number. Therefore, in order to investigate the genetic components and associations between traits that are related to IVP and natural reproduction, we estimated genetic parameters for numerical and percentage embryo traits, and the genetic associations between these traits and first calving in Guzerá cows.

\section{MATERIAL AND METHODS}

\section{Animals}

A total of 5173 aspirations in 1080 Guzerá female donors, daughters of 245 sires and 745 dams, were analyzed. The sessions were conducted in 16 herds between March 2005 and July 2013 in Minas Gerais State, Brazil. The animals were 1-20 years old when the OPU was performed. The genealogical file that was used to determine the relationships between the 1080 donors included five previous generations. The number of sessions varied from 1 to 62 per donor, and the intervals between OPU sessions for the same donor varied from 7 to 120 days. A total of 147 bulls were used for the IVF process.

\section{OPU and IVP}

The structures were obtained by transvaginal ovarian puncture guided by ultrasound as described by Seneda (2001), followed by IVF one day after aspiration. The OPU sessions were performed by an IVP technician using Mindray DP-2200 ultrasound equipment (Mindray, Shenzhen, China), with a 6.5-MHz microconvex transducer connected to a WTA ${ }^{\circledR}$ puncture guide (WTA, Cravinhos, SP, Brazil) and 18G catheters (JELCO ${ }^{\circledR}$ PLUS, Medex do Brasil, SP, Brazil). Immediately after the OPU, tubes containing the structures collected from the donors were taken to the farm's laboratory in 50-mL Falcon ${ }^{\mathrm{TM}}$ tubes (Corning ${ }^{\circledR}$ Glass Works, Corning, NY, USA), passed through an EmCom filter with phosphate-buffered saline (Nutricell, Campinas, SP, Brazil), and washed three times with the same solution used in the OPU process on a Petri dish.

Embryo selection, counting, and classification were conducted, considering the number of cumulus cells, the cumulus cell oocyte cytoplasm (grades I, II, and III), the number of cells without cumulus, and the number of expanded cells, atresic cells, and degenerated cells, as described by Lonergan (1992). Oocytes that were considered viable (grades I, II, and III) were washed in TCM-199 HEPES (Thermo Fisher Scientific, Waltham, MA, USA) supplemented with 10\% fetal calf serum, $50 \mu \mathrm{g}$ gentamicin, and $2.2 \mu \mathrm{g}$ pyruvate. Oocytes were packed into cryotubes (Uniscience, São Paulo, SP, Brazil) with $400 \mu \mathrm{L}$ maturation medium, constituted with TCM-199 bicarbonate (Thermo Fisher Scientific), supplemented with $10 \%$ fetal calf serum, $50 \mathrm{IU} \mathrm{hCG} / \mathrm{mL}, 0.5 \mu \mathrm{g} / \mathrm{mL}$ 
follicle-stimulating hormone, $1 \mu \mathrm{g} / \mathrm{mL}$ estradiol, $2.2 \mu \mathrm{g} / \mathrm{mL}$ pyruvate, and $70 \mu \mathrm{g} / \mathrm{mL}$ amikacin. The medium was covered with $300 \mu \mathrm{L}$ mineral oil under a $5 \% \mathrm{CO}_{2}$ in air atmosphere in order to transport it in a portable incubator at $38.5^{\circ} \mathrm{C}$.

Once in the laboratory, maturing oocytes were transferred to Petri dishes $(100 \times 20 \mathrm{~mm}$; TPP, Vitrocell, Campinas, SP, Brazil) in 100- $\mu \mathrm{L}$ microdrops of maturation medium (that was similar to the transportation medium). The oocytes were incubated for $24 \mathrm{~h}$ at $38.5^{\circ} \mathrm{C}$ under an atmosphere of $5 \% \mathrm{CO}_{2}$ in air. After maturation, the oocytes were washed in a fertilization medium [Tyrode's albumin lactate pyruvate (TALP)-IVF], and then $100-\mu \mathrm{L}$ microdrops of TALP supplemented with 10 $\mu \mathrm{g} / \mathrm{mL}$ heparin and $160 \mu \mathrm{L}$ penicillamine-hypotaurine-epinephrine were added.

The semen for the IVF was separated in 45\% Percoll 90 and centrifuged $(200 \mathrm{~g})$ for $30 \mathrm{~min}$, before being adjusted to obtain a final concentration of $100 \times 10^{3}$ viable spermatozoa per drop. IVF was conducted for $18 \mathrm{~h}$ at $39^{\circ} \mathrm{C}$ in an atmosphere of $5 \% \mathrm{CO}_{2}$ in air. After fertilization, the structures were washed and transferred to $100 \mu \mathrm{L}$ modified synthetic oviduct fluid medium and covered with mineral oil. The culture medium was renewed for each microdrop after 3 and 5 days (feeding), and after 6 days was taken to the farm in order to transfer the embryos to the receiving cows.

\section{Estimation of genetic parameters}

We analyzed the number of viable oocytes $\left(\mathrm{N}_{\mathrm{OV}}\right)$, grade I oocytes $\left(\mathrm{N}_{\mathrm{GI}}\right)$, cleaved embryos $\left(\mathrm{N}_{\mathrm{CLV}}\right)$, and viable embryos produced $\left(\mathrm{N}_{\mathrm{EMB}}\right)$, and the percentage of viable oocytes $\left(\mathrm{P}_{\mathrm{OV}}\right)$, grade I oocytes $\left(P_{G I}\right)$, cleaved embryos $\left(P_{C L V}\right)$, and viable embryos $\left(P_{E M B}\right)$. The percentage traits $\left(P_{G l}\right.$, $P_{C L V}$, and $P_{E M B}$ ) were calculated as proportions of $N_{O V}$, except for $P_{O V}$, which was calculated as a proportion of the total number of oocytes. Logarithmic transformation $\left(\log _{e} X+1\right)$ was applied to all of the variables (except for $\mathrm{P}_{\text {ov }}$ ) to obtain a normal distribution and estimate the variance components. $\mathrm{P}_{\text {ov }}$ could not be transformed to a normal distribution, and it followed a distribution that was approximately Gaussian. The variance components were estimated by the restricted maximum likelihood (REML) method using the ASREML software (Gilmour et al., 2002) with animal models. Estimates of the variance components were obtained by univariate analysis, and covariances by bivariate analysis. The heritability values obtained by the univariate analysis did not differ significantly from those obtained by the bivariate analysis.

Models proposed were as follows:

$$
\begin{aligned}
& \mathrm{Y}_{\mathrm{ijklmn}}=\mu+\mathrm{HY}_{\mathrm{i}}+\mathrm{BH}_{\mathrm{j}}+\mathrm{SE}_{\mathrm{k}}+\text { intOPU }_{\mathrm{i}}+\text { tech }_{\mathrm{m}}+\beta_{1} \\
& \left(\text { Age }_{i \mathrm{jklnm}}-\text { Age mean }\right)+\beta_{2}\left(\text { Age }_{i \mathrm{j} k l n m}-\text { Age mean }\right)^{2}+A_{i \mathrm{jklmn}}+P E_{i \mathrm{ijklm}}+\mathrm{e}_{\mathrm{ijklmn}} \\
& \mathrm{Y}_{\mathrm{ijklmn}}=\mu+\mathrm{HY}_{\mathrm{i}}+\mathrm{BH}_{\mathrm{j}}+\mathrm{SE}_{\mathrm{k}}+\text { intOPU }_{1}+\mathrm{tech}_{\mathrm{m}}+\beta_{1}\left(\mathrm{Age}_{\mathrm{ijklnm}}-\right.\text { Age mean) (Equation 2) } \\
& +\beta_{2}\left(\text { Age }_{\mathrm{ijk} k \mathrm{~m} m}-\text { Age mean }\right)^{2}+\mathrm{A}_{\mathrm{ijklmn}}+\text { IVFbull }_{\mathrm{ijk} k m}+P E_{\mathrm{ijklm}}+\mathrm{e}_{\mathrm{ijklmn}}
\end{aligned}
$$

where $Y_{i j k m n}$ represents the expected traits; $\mu$ is an intercept; $H Y_{i}$ is the fixed effect of herd of herdyear of OPU interactions $(i=1,2, \ldots, 84) ; B H_{j}$ is the fixed effect of the donors birth herd $(j=1,2 \ldots 16)$; $S E_{k}$ is the OPU season ( $\mathrm{k}=1$ or 2$)$; intOPU, is the fixed effect of the classes of interval between OPU sessions $(i=1,2, \ldots, 6)$; tech $_{m}$ is the fixed effect of the technician responsible for the OPU $(\mathrm{m}=$ $1,2, \ldots 7) ; A g e_{i j k l m n}$ is the age at OPU (in months) as a covariate (linear and quadratic effects); $P E_{i j k l m}$ is the random permanent environment effect $(o=1,2 \ldots 1080) ;$ IVFbull $_{i j k m}$ is the random effect of the bull used in IVF ( $p=1,2 \ldots 147)$; and $e_{i j k m n}$ represents the random residual terms. Both models 
included the random effect of animal $\left(\mathrm{A}_{\mathrm{ijk} / \mathrm{mn}}\right)$ in order to estimate the additive genetic component.

Model 1 was used to describe oocyte production traits $\left(\mathrm{N}_{\mathrm{OV}}, \mathrm{P}_{\mathrm{OV}}, \mathrm{N}_{\mathrm{Gl}}\right.$, and $\left.\mathrm{P}_{\mathrm{Gl}}\right)$ and model 2 for the embryo production traits $\left(\mathrm{N}_{\mathrm{CLV}}, \mathrm{P}_{\mathrm{CLV}}, \mathrm{N}_{\mathrm{EMB}}\right.$, and $\left.\mathrm{P}_{\mathrm{EMB}}\right)$. The second model is identical to the first, but includes IVFbull effect.

For the age at first calving $\left(\mathrm{A}_{\mathrm{FC}}\right)$ analysis, data from 3194 Guzerá cows were analyzed; the $A_{F C}$ varied from 680 to 1458 days. The univariate animal model included herd-year of the cow's birth and calving season as fixed effects.

Associations between OPU/IVP-related traits and $A_{F C}$ were analyzed by Pearson correlations $\left(\rho_{x, y}\right)$ between the estimated breeding values for both the natural $\left(A_{F C}\right)$ and artificial reproductive traits. From the 6850 animals in the pedigree file, the $30 \%(\mathrm{~N}=2055)$ more accurate estimated breeding values (for both traits) were used for the empiric analysis of association.

\section{RESULTS}

Table 1 presents the descriptive statistics of the data obtained. Overall, the analyzed traits presented high coefficients of variation $(\mathrm{CV}) . \mathrm{N}_{\mathrm{Gl}}$ and $\mathrm{P}_{\mathrm{Gl}}$ presented the highest $\mathrm{CV}$ for, respectively, counts and percentage groups of traits, while $\mathrm{P}_{\text {ov }}$ showed the lowest variation among the studied traits. When compared to the ranges of each count traits $\left(\mathrm{N}_{\mathrm{OV}}, \mathrm{N}_{\mathrm{Gl}}, \mathrm{N}_{\mathrm{CLV}}, \mathrm{N}_{\mathrm{EMB}}\right)$, the median values suggest that these variables assume a non-Gaussian distribution with very extreme values.

Table 1. Number of observations $(\mathrm{N})$, medians, means, standard deviations (SD), coefficients of variation (CV), and ranges of the traits analyzed (untransformed variables).

\begin{tabular}{l|c|c|c|c|c|c}
\hline Trait & $\mathrm{N}$ & Median & Mean & SD & CV (\%) & Range \\
\hline$N_{\text {OV }}$ & 5173 & 11.00 & 15.19 & 12.71 & 83.67 & $0-94$ \\
\hline$N_{G I}$ & 5173 & 2.00 & 3.32 & 3.61 & 100.09 & $0-40$ \\
\hline$N_{C L V}$ & 5173 & 8.00 & 11.91 & 10.04 & 84.29 & $0-71$ \\
\hline$N_{E M B}$ & 5173 & 4.00 & 5.96 & 5.68 & 95.30 & $0-48$ \\
\hline$P_{O V}$ & 5173 & $55.00 \%$ & $58.99 \%$ & $14.71 \%$ & 24.93 & $0-100 \%$ \\
\hline$P_{G I}$ & 5173 & $20.00 \%$ & $22.57 \%$ & $18.94 \%$ & 83.91 & $0-100 \%$ \\
\hline$P_{E M B}$ & 5173 & $68.50 \%$ & $65.50 \%$ & $19.52 \%$ & 29.80 & $0-100 \%$ \\
\hline
\end{tabular}

$\mathrm{N}_{\mathrm{OV}}=$ number of viable oocytes; $\mathrm{N}_{\mathrm{GI}}=$ number of grade I oocytes; $\mathrm{N}_{\mathrm{CLV}}=$ number of cleaved embryos; $\mathrm{N}_{\mathrm{EMB}}=$ number of transferable embryos; $P_{O V}=$ percentage of viable oocytes; $P_{G I}=$ percentage of grade I oocytes; $P_{C L V}=$ percentage of cleaved embryos; $P_{\mathrm{EMB}}=$ percentage of viable embryos.

Estimates of genetic parameters obtained from the univariate analysis of the oocyte and embryo productions traits are presented in Table 2. Genetic variance $\left(\sigma_{a}^{2}\right)$ for the count traits was proportionally higher (in relation to $\sigma^{2}$ ) than for the percentage traits. The same occurred for the permanent environment $\left(\sigma^{2}{ }_{p e}\right)$ component. $N_{o v}$ presented the highest repeatability $(0.32)$, followed by $N_{C L V}(0.27)$ and $N_{E M B}(0.21)$. All percentage traits $\left(P_{\text {oV }}, P_{G I}\right.$, $P_{C L V}$, and $P_{E M B}$ ) showed very low repeatability, varying from 0.01 to 0.08 . The proportion of the total variation accounted for by the bull (used in IVF) effect $\left(b^{2}\right)$ in $\mathrm{N}_{\mathrm{EMB}}$ (Table 2) was 1.1, 4.8, 4.7, and $9.5 \%$, respectively, for $\mathrm{N}_{C L V}, \mathrm{~N}_{E M B}, \mathrm{P}_{C L V}$, and $\mathrm{P}_{E M B}$. For $\mathrm{P}_{C L V}$ and $\mathrm{P}_{E M B}$ in particular, the bull effect accounted for more of the total variation than did genetic variation. Therefore, the improvement of male fertility using in vitro biotechnologies could be a useful tool for improving viable oocyte percentages in Guzerá cattle. 
Table 2. Estimates of environmental variance $\left(\sigma^{2}\right)$, additive genetic variance $\left(\sigma_{a}^{2}\right)$, permanent environment variance $\left(\sigma_{p e}^{2}\right)$, phenotypic variance $\left(\sigma^{2}\right)$, bull (semen used for in vitro fertilization) effect variance $\left(\sigma_{b}^{2}\right)$, proportion of the total variance accounted for by the bull effect $\left(b^{2}\right)$, and repeatability $(r)$ of the variables studied (transformed and untransformed).

\begin{tabular}{l|c|c|c|c|c|c|c}
\hline Trait & $\sigma_{e}^{2}$ & $\sigma^{2} a$ & $\sigma^{2} p e$ & $\sigma^{2} p$ & $\sigma^{2} b$ & $b^{2}$ & $r$ \\
\hline$N_{O V}$ & 0.2538 & 0.1026 & 0.1685 & 0.5249 & - & - & 0.321 \\
\hline$N_{G I}$ & 0.4384 & 0.0446 & 0.0809 & 0.5640 & - & - & 0.143 \\
\hline$N_{C L V}$ & 0.2778 & 0.0776 & 0.1362 & 0.4974 & 0.00574 & 0.011 & 0.273 \\
\hline$N_{E M B}$ & 0.3046 & 0.0728 & 0.1065 & 0.5084 & 0.02443 & 0.048 & 0.209 \\
\hline$P_{O V} P_{G I}$ & 197.8740 & 7.8983 & 1.6124 & 207.3800 & - & - & 0.080 \\
\hline$P_{C L V}$ & 0.3470 & 0.0129 & 0.0264 & 0.3864 & - & - & 0.068 \\
\hline$P_{\text {EMB }}$ & 0.1189 & 0.0019 & 0.0019 & 0.1288 & 0.0061 & 0.047 & 0.015 \\
\hline
\end{tabular}

${ }^{*}$ Variable not log-transformed $\left(\log _{\mathrm{e}} \mathrm{X}+1\right) . \mathrm{N}_{\mathrm{oV}}=$ number of viable oocytes; $\mathrm{N}_{\mathrm{GI}}=$ number of grade I oocytes; $\mathrm{N}_{\mathrm{CLV}}=$ number of cleaved embryos; $\mathrm{N}_{\mathrm{EMB}}=$ number of transferable embryos; $\mathrm{P}_{\mathrm{OV}}=$ percentage of viable oocytes; $\mathrm{P}_{\mathrm{Gl}}=$ percentage of grade I oocytes; $P_{C L V}=$ percentage of cleaved embryos; $P_{E M B}=$ percentage of viable embryos.

Table 3 presents the heritability estimates (on the diagonal, in bold), genetic correlations (under the diagonal), and phenotypic correlations (above the diagonal) for the traits analyzed. Heritabilities for the oocyte production traits varied from $0.08\left(\mathrm{~N}_{\mathrm{GI}}\right)$ to $0.19\left(\mathrm{~N}_{\mathrm{OV}}\right)$, whereas heritabilities for the percentage traits were low, and varied from $0.01\left(\mathrm{P}_{\mathrm{CLV}}\right)$ to $0.07\left(\mathrm{P}_{\mathrm{EMB}}\right)$.

Table 3. Heritability estimates (diagonal), genetic correlations (under the diagonal), and phenotypic correlations (above the diagonal) of the variables analyzed and their associated standard errors (in parentheses).

\begin{tabular}{|c|c|c|c|c|c|c|c|c|}
\hline Trait & Nov & $\mathrm{N}_{\mathrm{GI}}$ & $\mathrm{N}_{\mathrm{CLV}}$ & $\mathrm{N}_{\text {EMB }}$ & Pov & $\mathrm{P}_{\mathrm{GI}}$ & $\mathrm{P}_{\mathrm{CLV}}$ & $P_{E M B}$ \\
\hline Nov & $0.19(0.05)$ & $0.64(0.01)$ & $0.90(0.01)$ & $0.72(0.01)$ & $0.35(0.01)$ & $-0.40(0.02)$ & $-0.09(0.01)$ & $-0.20(0.01)$ \\
\hline $\mathrm{N}_{\mathrm{GI}}$ & $0.96(0.03)$ & $0.08(0.03)$ & $0.63(0.01)$ & $0.50(0.01)$ & $0.24(0.01)$ & $0.61(0.02)$ & $-0.04(0.01)$ & $-0.07(0.01)$ \\
\hline NcLV & $0.88(0.01)$ & $0.98(0.01)$ & $0.16(0.04)$ & $0.79(0.01)$ & $0.27(0.01)$ & $-0.34(0.01)$ & $0.28(0.01)$ & $-0.02(0.02)$ \\
\hline $\mathrm{N}_{\mathrm{EMB}}$ & $0.68(0.05)$ & $0.89(0.07)$ & $0.87(0.05)$ & $0.14(0.04)$ & $0.24(0.01)$ & $-0.22(0.01)$ & $0.30(0.01)$ & $0.54(0.01)$ \\
\hline Pov & $0.40(0.18)$ & $0.51(0.21)$ & $0.41(0.21)$ & $0.33(0.22)$ & $0.04(0.02)$ & $-0.11(0.01)$ & $0.09(0.01)$ & $0.01(0.01)$ \\
\hline $\mathrm{P}_{\mathrm{GI}}$ & $-0.22(0.16)$ & $-0.56(0.25)$ & $-0.68(0.22)$ & $-0.75(0.18)$ & $-0.51(0.24)$ & $0.03(0.02)$ & $0.06(0.01)$ & $0.14(0.01)$ \\
\hline$P_{C L V}$ & $-0.52(0.25)$ & $-0.52(0.25)$ & $-0.41(0.25)$ & $-0.45(0.25)$ & $0.36(0.25)$ & $0.30(0.28)$ & $0.01(0.01)$ & $0.46(0.01)$ \\
\hline$P_{\text {EMB }}$ & $-0.36(0.17)$ & $-0.28(0.19)$ & $-0.34(0.21)$ & $0.23(0.21)$ & $0.15(0.20)$ & $0.12(0.23)$ & $0.38(0.26)$ & $0.07(0.03)$ \\
\hline
\end{tabular}

$\mathrm{N}_{\mathrm{OV}}=$ number of viable oocytes; $\mathrm{N}_{\mathrm{GI}}=$ number of grade I oocytes; $\mathrm{N}_{\mathrm{CLV}}$ = number of cleaved embryos; $\mathrm{N}_{\mathrm{EMB}}=$ number of transferable embryos; $P_{O V}=$ percentage of viable oocytes; $P_{G I}=$ percentage of grade I oocytes; $P_{C L V}=$ percentage of cleaved embryos; $P_{E M B}=$ percentage of viable embryos.

Heritabilities for $\mathrm{N}_{\mathrm{OV}}$ and $\mathrm{N}_{\mathrm{EMB}}$, which are traits strongly related to IVP success, were low to moderate $\left(0.19 \pm 0.05\right.$ and $0.14 \pm 0.04$, respectively). The genetic correlation between $\mathrm{N}_{\mathrm{OV}}$ and $\mathrm{N}_{\mathrm{EMB}}$ was moderate to high (0.68). However, negative associations were found between $\mathrm{N}_{\mathrm{ov}}$ and all of the percentage traits $\left(P_{G 1}, P_{C L V}\right.$, and $\left.P_{E M B}\right)$, except for $P_{O V} \cdot P_{C L V}$ presented very low genetic component.

Table 4 presents Pearson correlation coefficients between the $30 \%$ (2055 individuals) more accurate estimated breeding values (that had genealogical connections with both the naturaland artificial-trait dataset) included in the pedigree file used in the $A_{F C}$ analysis, and the oocyte/ embryo production traits studied.

Table 4. Pearson correlation coefficients $\left(\rho_{x y}\right)$ between age at first calving $\left(A_{F C}\right)$ and embryo-production-trait estimated breeding values in the population studied $(N=2055)$.

\begin{tabular}{l|c|c|c|c|c|c|c|c}
\hline Trait & NoV & $N_{G I}$ & NCLV & NEMB & PoV & PGI & PCLV & PEMB \\
\hline A FC $_{\text {f }}$ & -0.003 & 0.008 & 0.021 & -0.006 & 0.091 & 0.107 & 0.013 & -0.012 \\
\hline
\end{tabular}

$\mathrm{N}_{\mathrm{OV}}=$ number of viable oocytes; $\mathrm{N}_{\mathrm{GI}}$ = number of grade I oocytes; $\mathrm{N}_{\mathrm{CLV}}=$ number of cleaved embryos; $\mathrm{N}_{\mathrm{EMB}}$, number of transferable embryos; $P_{O V}$, percentage of viable oocytes; $P_{G I}=$ percentage of grade I oocytes; $P_{C L V}=$ percentage of cleaved embryos; $\mathrm{P}_{\mathrm{EMB}}=$ percentage of viable embryos. 
There was only a weak association between the traits related to embryo production and $A_{F C}$ in the Guzerá breed, which varied from $-0.003\left(\mathrm{~N}_{\mathrm{OV}}\right)$ to $0.107\left(\mathrm{P}_{\mathrm{GI}}\right)$.

\section{DISCUSSION}

\section{OPU and IVP}

Pontes et al. $(2010,2011)$ reported values of $23.4 \pm 0.7,12.1 \pm 3.9$, and $8.0 \pm 2.7$ of viable oocytes obtained per session in Nellore, Gir, and Holstein cattle breeds, respectively. The high values obtained for Nellore and Guzerá (this study) cattle could be associated with selection for reproductive traits. Selection for better reproductive performance can indirectly select animals for higher oocyte numbers and embryo production. In B. taurus, Merton et al. (2009) reported means of $7.8,4.4$, and 1.8 for the number of viable oocytes, the number of cleaved embryos, and the number of embryos produced, respectively, and mean percentages of $26.6,53.6$, and $22.4 \%$ for grade I oocytes, cleaved embryos, and embryos produced (as proportions of the number of viable oocytes), respectively. Results of the present study indicate that Guzerá breed oocyte and embryo production traits differ from those of $B$. taurus breeds as reported by Carvalho et al. (2008) in Zebu cattle, particularly when considering absolute number (count) traits $\left(\mathrm{N}_{\mathrm{OV}}, \mathrm{N}_{\mathrm{Gl}}, \mathrm{N}_{\mathrm{CLV}}\right.$, and $\left.\mathrm{N}_{\mathrm{EMB}}\right)$.

\section{Heritabilities for in vitro embryo production traits}

In general, count traits $\left(\mathrm{N}_{\mathrm{OV}}, \mathrm{N}_{\mathrm{Gl}}, \mathrm{N}_{\mathrm{CLV}}\right.$, and $\left.\mathrm{N}_{\mathrm{EMB}}\right)$ exhibited higher repeatabilities than the percentage traits $\left(P_{O V}, P_{G I}, P_{C L V}\right.$, and $\left.P_{E M B}\right)$. Therefore, it may be possible to categorize donors after the first collection by the number of oocytes punctured, in order to facilitate management inside the laboratory or even to identify donors that will have a good or poor lifetime performance with OPU/ IVP technologies.

The genetic components reported for percentage traits suggest that selection for higher percentages of oocyte and/or embryos may not be as successful as directly selecting for the total number of structures. That suggests that improvement in technological and environmental factors may be more viable in order to increase oocyte and embryo proportions per session.

Merton et al. (2009) reported heritabilities of $0.25 \pm 0.06,0.19 \pm 0.04$, and $0.21 \pm 0.04$ for the number of viable oocytes, the number of cleaved embryos, and the total number of embryos produced, respectively, in Holstein female donors using univariate analysis following a sire model. Heritabilities reported in the present study follow a similar pattern. The lower values of heritability when compared to previous study may happen because Merton et al., (2009) utilized sire models, which are frequently reported to overestimate additive genetic variation in some cases.

Genetic correlations for $\mathrm{N}_{\mathrm{OV}}$ related to $\mathrm{N}_{\mathrm{EMB}}(0.68)$ and $\mathrm{P}_{\mathrm{EMB}}(-0.36)$ suggest that selection for $\mathrm{N}_{\mathrm{ov}}$ may increase the total number of embryos produced, but will decrease the percentage of viable embryos (as a proportion of viable oocytes cultured). Both phenotypic and genetic correlations for $\mathrm{P}_{\mathrm{GI}}$ were negative, excepted for $\mathrm{P}_{\mathrm{CLV}}$ and $\mathrm{P}_{\mathrm{EMB}}$, indicating an important association between oocyte quality and IVP success.

The results of the present study indicate that $B$. indicus embryos' capacity to cleave is almost non-responsive to selection.

Genetic correlations between embryo production traits and natural reproduction suggest that selection for embryo production traits would probably not affect the $A_{F C}$. Also, this may 
indicate weak or non-existent association between precocity and artificial reproductive (OPU/IVF) performance in Guzerá cows. Merton et al. (2009) also reported a weak association between embryo production traits and reproductive indices of the sires' daughters in Holstein cattle. Baruselli et al. (2014) found no effect of the number of antral follicles (on estrus) on pregnancy rates in Nellore cows. Considering that the number of antral follicles present in the ovary is closely related to the number of oocytes obtained in OPU, the lack of an association between these traits reinforces the idea that natural and artificial reproduction may have a complex and indirect association; therefore, oocyte and embryo production traits may not be appropriate indicators of natural reproductive performance in cows. However, it also suggests that no undesirable effects on $A_{F C}$ are expected when selecting for embryo production traits.

Overall, results of this study suggest that selection for IVP efficiency can be applied in Guzerá cattle due to the amount of genetic variation present in the traits analyzed. $\mathrm{N}_{\mathrm{ov}}$ seems to respond well to selection by indirectly increasing the number of total embryos produced, due to its moderate heritability and positive association with $\mathrm{N}_{\mathrm{EMB}}$. Direct selection for $\mathrm{N}_{\mathrm{EMB}}$ could also be applied, but would require more time for data acquisition, and, consequently, greater cost.

The percentage of total variation accounted for by the bull effect for $\mathrm{N}_{\mathrm{CL}}, \mathrm{N}_{\mathrm{EMB}}, \mathrm{P}_{\mathrm{CLV}}$, and $\mathrm{P}_{\mathrm{EMB}}$ indicates the importance of male fertility for embryo production in the Guzerá breed. Future studies should investigate the genetic components of bull-related embryo production traits and their performance using IVP biotechnology.

We found only weak associations between the estimated breeding values for $A_{F C}$ and the oocyte/embryo production traits. Pearson correlation coefficient obtained between the $A_{F C}$ and $N_{\mathrm{oV}}$ estimated breeding values also supports the selection for $N_{\mathrm{ov}}$ to improve OPU/IVP results in the Guzerá breed, as there should be no effect on the population's genetic potential for $\mathrm{A}_{\mathrm{FC}}$ when selecting for $\mathrm{N}_{\mathrm{OV}}$.

\section{Conflicts of interest}

The authors declare no conflict of interest.

\section{ACKNOWLEDGMENTS}

We thank Cenatte Embriões Ltda. for kindly providing the data for this study. We are also grateful to Fapemig and the government funding agency Conselho Nacional de Desenvolvimento Científico e Tecnológico (CNPq) and Coordenação de Aperfeiçoamento de Pessoal de Nível Superior (CAPES) for financial support.

\section{REFERENCES}

Baruselli PS, Sá Filho MF, Ferreira RM, Sales JNS, et al. (2012). Manipulation of follicle development to ensure optimal oocyte quality and conception rates in cattle. Reprod. Domest. Anim. 47 (Suppl 4): 134-141. http://dx.doi.org/10.1111/j.1439$\underline{0531.2012 .02067 . x}$

Baruselli PS, Vieira LM, Guerreiro BM, Soares JG, et al. (2014). Relationship between antral follicle population and pregnancy results following fixed-time $\mathrm{Al}$ in Nelore (Bos indicus) cows. Proceedings of the 28th Annual Meeting of the Brazilian Embryo Technology Society (SBTE), Natal, RN, Brazil.

Carvalho JBP, Carvalho NAT, Reis EL, Nichi M, et al. (2008). Effect of early luteolysis in progesterone-based timed Al protocols in Bos indicus, Bos indicus x Bos taurus, and Bos taurus heifers. Theriogenology 69: 167-175. http://dx.doi.org/10.1016/j. theriogenology.2007.08.035 
de Torres-Júnior JR, Pires MF, de Sá WF, FerreiraAde M, et al. (2008). Effect of maternal heat-stress on follicular growth and oocyte competence in Bos indicus cattle. Theriogenology 69: 155-166. http://dx.doi.org/10.1016/j.theriogenology.2007.06.023

Gilmour AR, Gogel BJ, Cullis BR, Welham SJ, et al. (2002). ASReml User Guide Release 1.0. VSN International Ltd.

Guerreiro BM, Batista EOS, Vieira LM, Sá Filho MF, et al. (2014). Plasma anti-Mullerian hormone: an endocrine marker for in vitro embryo production from Bos taurus and Bos indicus donors. Domest. Anim. Endocrinol. 49: 96-104. http://dx.doi. org/10.1016/j.domaniend.2014.07.002

IETS (International Embryo Transfer Society) Data Retrieval Committee (2014). Statistics of embryo collection in farm animals. Available at [www.iets.org]. Accessed June 10, 2015.

Kadarmideen HN, Mazzoni G, Watanabe YF, Strøbech L, et al. (2015). Genomic selection of in vitro produced and somatic cell nuclear transfer embryos for rapid genetic improvement in cattle production. Anim. Reprod. 12: 389-396.

König S, Bosselmann F, von Borstel UU and Simianer H (2007). Genetic analysis of traits affecting the success of embryo transfer in dairy cattle. J. Dairy Sci. 90: 3945-3954. http://dx.doi.org/10.3168/jds.2007-0089

Lonergan P (1992). Studies in the in vitro maturation, fertilization and cultivation of bovine follicular oocytes. Doctoral thesis, National University of Ireland.

Machado SA, Reichenbach HD, Weppert M, Wolf E, et al. (2006). The variability of ovum pick-up response and in vitro embryo production from monozygotic twin cows. Theriogenology 65: 573-583. http://dx.doi.org/10.1016/j. theriogenology.2005.04.032

Madalena FE (2012). Animal breeding and development - South American perspective. J. Anim. Breed. Genet. 129: 171-172. http://dx.doi.org/10.1111/j.1439-0388.2012.01006.x

Merton JS, de Roos AP, Mullaart E, de Ruigh L, et al. (2003). Factors affecting oocyte quality and quantity in commercial application of embryo technologies in the cattle breeding industry. Theriogenology 59: 651-674. http://dx.doi.org/10.1016/ $\underline{\text { s0093-691X(02)01246-3 }}$

Merton JS, Ask B, Onkundi DC, Mullaart E, et al. (2009). Genetic parameters for oocyte number and embryo production within a bovine ovum pick-up-in vitro production embryo-production program. Theriogenology 72: 885-893. http://dx.doi. org/10.1016/j.theriogenology.2009.06.003

Nicholas FW and Smith C (1983). Increased rates of genetic change in dairy cattle by embryo transfer and splitting. Anim. Prod. 36: 341-353. http://dx.doi.org/10.1017/S0003356100010382

Peixoto MG, Pereira CS, Bergmann JA, Penna VM, et al. (2004). Genetic parameters of multiple ovulation traits in Nellore females. Theriogenology 62: 1459-1464. http://dx.doi.org/10.1016/j.theriogenology.2004.02.019

Penna VM, Verneque RS, Teodoro RL, Melo MVM, et al. (2002). Utilization of Moet Nucleus in the improvement of Guzerá. 7th World Congress on Genetics Applied to Livestock Production, Montpellier, France.

Ponter AA, Guyader-Joly C, Nuttinck F, Grimard B, et al. (2012). Oocyte and embryo production and quality after OPU-IVF in dairy heifers given diets varying in their n-6/n-3 fatty acid ratio. Theriogenology 78: 632-645. http://dx.doi.org/10.1016/j. theriogenology.2012.03.009

Pontes JH, Silva KC, Basso AC, Rigo AG, et al. (2010). Large-scale in vitro embryo production and pregnancy rates from Bos taurus, Bos indicus, and indicus-taurus dairy cows using sexed sperm. Theriogenology 74: 1349-1355. http://dx.doi. org/10.1016/j.theriogenology.2010.06.004

Pontes JH, Melo Sterza FA, Basso AC, Ferreira CR, et al. (2011). Ovum pick up, in vitro embryo production, and pregnancy rates from a large-scale commercial program using Nelore cattle (Bos indicus) donors. Theriogenology 75: $1640-1646$. http://dx.doi.org/10.1016/j.theriogenology.2010.12.026

Rutledge JJ (2004). Technology innovations to enhance livestock agribusiness. Wartazoa 14: 58-60.

Sales JN, Iguma LT, Batista RI, Quintão CC, et al. (2015). Effects of a high-energy diet on oocyte quality and in vitro embryo production in Bos indicus and Bos taurus cows. J. Dairy Sci. 98: 3086-3099. http://dx.doi.org/10.3168/jds.2014-8858

Seneda MM (2001). Aspectos técnicos e biológicos da obtencão in vitro de ovócitos bovinos. 76p. Doctoral thesis, Faculdade de Ciência Agrárias e Veterinárias, Universidade Estadual Paulista, Jaboticabal, SP, Brazil.

Simões R, Feitosa WB, Siqueira AFP, Nichi M, et al. (2013). Influence of bovine sperm DNA fragmentation and oxidative stress on early embryo in vitro development outcome. Reproduction 146: 433-441. http://dx.doi.org/10.1530/REP-13-0123

Tonhati H, Lôbo RB and Oliveira HN (1999). Repeatability and heritability of response to superovulation in Holstein cows. Theriogenology 51: 1151-1156. http://dx.doi.org/10.1016/S0093-691X(99)80018-1 